\title{
Perubahan pengetahuan penjamah makanan hotel setelah penyuluhan higiene perorangan
}

\author{
Hapsari Sulistya Kusuma ${ }^{1 *}$, Amalia Pasanda ${ }^{1}$, Kartika Nugraheni ${ }^{1}$, Choirun Nissa ${ }^{2}$
}

\section{ABSTRACT}

Background : Personal hygiene food handlers in food processing is very important because with the application of good hygiene can minimize the possibility of food contamination. The personal hygiene can be influenced by some factors, for instance knowledge and behaviors of food handlers. Lack of knowledge, inappropriate behaviors towards personal hygiene can be changed by giving the right information.

Objective : This study aims to determine differences in knowledge of food handlers before and after counseling.

Methods : This was a quasi-experimental one group pretest posttest design. The sample of this study was 18 food handlers in Patra Jasa Hotel selected by total sampling method. Knowledge data obtained from the total score from the correct answer in the questionnaire. The data was analyzed using Wilcoxon test.

Results : This study showed that the increases in knowledge of food handlers increased by $22 \%$. Statistical analysis showed knowledge before and after nutrition extension $(p=0.001)$.

Conclusions : there was difference in knowledge of food handlers before and after personal hygiene counseling.

Keywords : personal hygiene; food handlers; knowledge

\begin{abstract}
ABSTRAK
Latar Belakang : Higiene perorangan merupakan cara perawatan diri manusia untuk memelihara kesehatan mereka. Higiene perorangan penjamah makanan dalam proses pengolahan makanan sangat penting, karena dengan penerapan higiene yang baik dapat meminimalisir kemungkinan terjadinya kontaminasi pada makanan. Penerapan higiene perorangan dapat dipengaruhi oleh pengetahuan penjamah makanan tentang higiene perorangan saat bekerja. Pengetahuan yang kurang baik dalam hal higiene perorangan dapat ditingkatkan dengan menyampaikan informasi atau memberikan pendidikan melalui penyuluhan.

Tujuan : Penelitian ini bertujuan untuk mengetahui perbedaan pengetahuan penjamah makanan sebelum dan setelah diberikan penyuluhan.

Metode : Jenis penelitian yaitu quasi eksperimen dengan pendekatan one group pretest posttest. Sampel penelitian adalah 18 penjamah makanan di hotel Patra Jasa yang dipilih secara total sampling. Hotel Patra Jasa adalah hotel konvensional yang menyediakan banyak ruangan besar untuk kegiatan-kegiatan besar sehingga menyelenggarakan makanan dalam jumlah besar pula. Data pengetahuan diperoleh dari jumlah skor benar dari total pertanyaan pada kuesioner pengetahuan. Analisis statistik menggunakan uji Wilcoxon untuk mengetahui perbedaan pengetahuan penjamah makanan sebelum dan setelah diberikan penyuluhan tentang higiene perorangan.

Hasil : Terjadi peningkatan pengetahuan penjamah makanan sebelum dan setelah diberikan penyuluhan sebesar $22 \%$. Analisis statistik menunjukkan perbedaan pengetahuan yang signifikan sebelum dan setelah penyuluhan $(p=0,001)$.

Simpulan : Ada perbedaan pengetahuan penjamah makanan sebelum dan setelah diberikan penyuluhan.
\end{abstract}

Kata kunci : higiene perorangan; penjamah makanan; pengetahuan.

\section{PENDAHULUAN}

Dewasa ini, sektor pariwisata makin erat kaitannya dengan kebutuhan akomodasi untuk singgah dan bermalam. Kebutuhan akomodasi terpenuhi dengan makin banyaknya hotel yang berdiri. Tidak hanya melayani kebutuhan untuk bermalam,

\footnotetext{
1. Program Studi Ilmu Gizi, Fakultas Ilmu Keperawatan dan Kesehatan, Universitas Muhammadiyah Semarang. Jl. Kedungmundu Raya No. 22 Semarang, Tlp: (024) 76740230

2. Program Studi Ilmu Gizi, Departemen Ilmu Gizi, Fakultas Kedokteran, Universitas Diponegoro. Jl. Prof. Soedarto SH Tembalang, Semarang 50275

*Korespondensi: ,Email : hapsa31@yahoo.co.id
}

saat ini hotel telah dilengkapi dengan ruang pertemuan, fasilitas olahraga, dan fasilitas restoran, yang tergantung dari klasifikasi hotel tersebut. Restoran hotel memberikan layanan makanan dan minuman yang tentunya harus memenuhi syarat higiene sanitasi. Syarat tersebut memuat bangunan, fasilitas, peralatan, ketenagaan, makanan secara bersama sama berperan dalam menjamin makanan yang dihasilkan tidak terkontaminasi kimia, kuman sehingga aman dikonsumsi. Penelitian di hotel berbintang di Jakarta menunjukkan bahwa higiene personal, higiene makanan, higiene peralatan dan higiene dapur memiliki pengaruh secara bersama sama terhadap kualitas makanan. ${ }^{1}$

Ketenagaan, dalam hal ini penjamah makanan memiliki peran besar dalam transmisi kuman, racun, 
karena tangan menjadi kendaraan utama terjadinya kontaminasi silang agen infeksius pada makanan siap santap. ${ }^{2}$ Penjamah makanan dimungkinkan membawa kuman patogen seperti Hepatitis A, norovirus, typhoidal Salmonella, Staphylococcus aureus, dan Shigella sp melalui tangan, luka, mulut, kulit, dan rambut. Penjamah makanan juga dapat membawa patogen seperti E. coli dan Salmonella non-typhoidal selama periode penyembuhan paska gangguan saluran cerna. $^{3}$

Transmisi bakteri enteropatogenik usus dapat mengkontaminasi makanan melalui feses penjamah makanan yang terkena baik secara langsung maupun tak langsung. Media yang ditularkan dapat melalui makanan, air, kuku, dan tangan melalui perilaku yang tidak higiene. ${ }^{4}$ Strain tertentu seperti E coli terbukti merupakan bakteri patogen dan dapat menyebabkan keracunan makanan yang parah. ${ }^{5}$

Penelitian di Iran menunjukkan sebanyak $21,8 \%$ kuku penjamah makanan di hotel memiliki Staphylococcus aureus, E. coli (15,6\%), dan coliform $(9,4 \%){ }^{4}$ Hal ini mengindikasikan adanya kontaminasi pada makanan, air, atau penjamah makanan serta perilaku higiene yang buruk ketika proses penyelenggaraan makanan. ${ }^{6}$

Penjamah makanan diharapkan memiliki perilaku higiene yang baik sehingga menurunkan terjadinya kontaminasi silang, dan pada akhirnya dapat melindungi konsumen dari penyakit yang disebabkan oleh makanan. Agar penjamah makanan dapat berperilaku yang tepat ketika proses penyelenggaraan makanan, pengetahuan dan pelatihan menjadi bagian yang penting dalam bekerja. ${ }^{7}$ Pengetahuan penjamah makanan menjadi faktor penting sebagaimana kebijakan yang dibuat melalui Permenkes No 1096/MENKES/PER/VI/2011 tentang higiene sanitasi jasa boga menyebutkan bahwa upaya yang dilakukan untuk meningkatkan pengetahuan dan ketrampilan penjamah makanan dapat dilakukan melalui pelatihan / kursus higiene sanitasi makanan. ${ }^{8}$

Penelitian di kampus Depok UI menguatkan fakta bahwa pengetahuan mengenai makanan sebagai media penyakit dan perilaku mencuci tangan memiliki hubungan erat dengan kontaminasi bakteri E. coli. ${ }^{9}$ Berdasar hal tersebut, penelitian ini ingin melihat pengetahuan awal penjamah makanan dan untuk mengetahui perbedaaan pengetahuan penjamah makanan di hotel Patra Jasa Semarang sebelum dan setelah diberikan penyuluhan tentang higiene perorangan.

\section{BAHAN DAN METODE}

Jenis penelitian adalah quasi eksperimen dengan pendekatan one group pretest posttest. Penelitian dilakukan pada seluruh penjamah makanan di hotel Patra Jasa Semarang, yaitu sebanyak 18 orang.

Data primer dalam penelitian ini meliputi identitas lengkap sampel, pengetahuan tentang penerapan higiene perorangan penjamah makanan. Data sekunder meliputi jumlah penjamah makanan dan lama kerja.

Data pengetahuan diperoleh melalui wawancara menggunakan kuesioner yang berjumlah 8 pertanyaan. Jumlah skor benar dihitung berdasarkan total pertanyaan kuesioner pengetahuan, kemudian diklasifikasikan menjadi tiga kategori yaitu : baik jika nilai $76-100 \%$, cukup jika nilai $56-75 \%$, kurang jika nilai $40-55 \% .{ }^{10}$ Uji statistik yang digunakan yaitu uji Wilcoxon, pada tingkat kepercayaan $95 \%$ dan batas kemaknaan $\mathrm{P}<0,05$.

\section{HASIL}

\section{Karakteristik Penjamah Makanan}

Permenkes No 1096/MENKES/PER/VI/2011 tentang Higiene Sanitasi Jasa Boga, penjamah makanan didefinisikan sebagai orang yang secara langsung mengelola makanan. Sebanyak 18 orang penjamah makanan bekerja di Main Kitchen Kendalisodo Brasserie, Restoran di Hotel Patra Jasa Semarang, yang terdiri dari 1 Sous Chef, 1 Chef de Partie, 2 Chef de Pattiserie, 7 Supervisor Cook, dan 7 Cook Help. Data karakteristik penjamah makanan yang bekerja di hotel Patra Jasa Semarang dapat dilihat pada Tabel 1.

Tabel 1. Karakteristik Penjamah Makanan

\begin{tabular}{lcc}
\hline \multicolumn{1}{c}{ Karakteristik } & (n) & (\%) \\
\hline Umur (tahun) & & \\
$26-45$ & 11 & 61 \\
$46-65$ & 7 & 39 \\
Jenis kelamin & & \\
$\quad$ Laki-laki & 13 & 72 \\
$\quad$ Perempuan & 5 & 28 \\
Tingkat pendidikan & & \\
$\quad$ SMA/SMK & 14 & 78 \\
$\quad$ Diploma & 1 & 5 \\
$\quad$ Sarjana & 3 & 17 \\
Lama kerja (tahun) & & \\
1-10 & 3 & 17 \\
$>10$ & 15 & 83 \\
\hline
\end{tabular}

Mayoritas penjamah makanan telah bekerja lebih dari 10 tahun. Untuk mendukung performa dalam bekerja, penjamah makanan diberikan briefing setiap pergantian shift untuk menyampaikan informasi secara berulang perihal higiene personal dan hal lain terkait pelayanan makanan. Wawancara menggunakan kuesioner dilakukan pada penjamah makanan sebelum dan sesudah pemberian materi penyuluhan. 
Sebanyak 13 penjamah makanan (72\%) memiliki pengetahuan dengan kategori baik (Tabel 2). Hasil penelitian mengungkapkan rata-rata skor pre test tingkat pengetahuan penjamah makanan adalah 6,61 $\pm 0,200$. Hasil post test tingkat pengetahuan higiene perorangan kategori baik sebanyak 17 responden (94\%) dengan rata-rata skor post test tingkat pengetahuan penjamah makanan adalah 7,11 $\pm 0,178$.

Kuesioner sebanyak 8 pertanyaan diajukan kepada penjamah makanan dengan pilihan benar dan salah sesuai higiene sanitasi tenaga yang termuat dalam Permenkes No 1096. Materi yang diberikan meliputi perlakuan penjamah makanan yang sakit, cuci tangan, penggunaan benda pribadi atau perhiasan, manfaat kebiasaan hidup bersih, dan faktor-faktor yang mempengaruhi higiene perorangan (tabel 3).

Terjadi peningkatan jumlah skor benar dari tiap pertanyaan dalam kuesioner sebelum dan sesudah pemberian materi, bahkan semua penjamah makanan dapat menjawab pertanyaan terkait penerapan higiene perorangan dan momen cuci tangan yang benar setelah adanya pemberian materi (tabel 3). Beberapa pertanyaan yang sering dijawab salah pada pre tes oleh responden yaitu tentang (1) faktor-faktor yang mempengaruhi higiene perorangan $(72,2 \%)$, (2) penyakit infeksi yang tidak boleh diderita penjamah makanan $(66,7 \%)$, (3) hal yang tidak boleh dilakukan oleh penjamah saat bekerja $(44,4 \%)$ dan (4) perlakuan pada penjamah makanan yang sakit $(44,4 \%)$. Sebaliknya, beberapa pertanyaan yang sering dijawab benar saat pre tes adalah tentang (1) penerapan higiene perorangan $(88,8 \%)$, (2) moment cuci tangan $(77,7 \%),(3)$ manfaat higiene perorangan $(61,1 \%)$ dan (4) perlakuan pada perhiasan dan benda pribadi pada saat bekerja $(61,1 \%)$.

Tabel 2. Pengetahuan Sebelum dan Sesudah Penyuluhan

\begin{tabular}{lcccc}
\hline \multirow{1}{*}{ Variabel } & \multicolumn{2}{c}{ Pre test } & \multicolumn{2}{c}{ Post test } \\
\cline { 2 - 5 } & $\mathbf{n}$ & $\mathbf{\%}$ & $\mathbf{N}$ & $\mathbf{\%}$ \\
\hline Pengetahuan & & & & \\
Baik & 13 & 72 & 17 & 94 \\
Cukup & 5 & 28 & 1 & 6 \\
Kurang & 0 & 0 & 0 & 0 \\
\hline Jumlah & $\mathbf{1 8}$ & $\mathbf{1 0 0}$ & $\mathbf{1 8}$ & $\mathbf{1 0 0}$ \\
\hline
\end{tabular}

Tabel 3. Distribusi Frekuensi Jawaban Kuesioner

\begin{tabular}{llccc}
\hline \multicolumn{1}{c}{ Pertanyaan } & \multicolumn{2}{c}{ Pre tes (\%) } & \multicolumn{2}{c}{ Post tes (\%) } \\
\cline { 2 - 5 } & Benar & Salah & Benar & Salah \\
\hline 1. Penyakit yang tidak boleh diderita penjamah makanan & 33.3 & 66.7 & 55.5 & 44.4 \\
2. Hal yang tidak boleh dilakukan oleh penjamah makanan saat bekerja & 55.5 & 44.4 & 77.7 & 22.2 \\
3. Penerapan higiene perorangan & 88.8 & 11.1 & 100 & - \\
4. Moment cuci tangan yang benar & 77.7 & 22.2 & 100 & - \\
5. Perlakuan pada perhiasan dan benda-benda pribadi pada saat bekerja & 61.1 & 38.8 & 77.7 & 22.2 \\
6. Perlakuan pada penjamah makanan yang sakit & 55.5 & 44.4 & 66.7 & 33.3 \\
7. Manfaat higiene perorangan & 61.1 & 38.8 & 88.9 & 11.1 \\
8. Faktor-faktor yang mempengaruhi higiene perorangan & 27.7 & 72.2 & 44.4 & 55.6 \\
\hline
\end{tabular}

\section{Perbedaan Skor Pengetahuan Higiene perorangan Penjamah Makanan}

Hasil uji statistik menggunakan Wilcoxon Signed ranks test menunjukkan terdapat perbedaan yang signifikan dengan $p$ value 0,005 ( $p$ value $<0,05$ ) sebelum dan setelah diberikan penyuluhan. Hal ini diperkuat melalui tabel 2 yang menunjukkan bahwa terjadi peningkatan pengetahuan penjamah makanan sebanyak $22 \%$ tentang higiene perorangan di hotel Patra Jasa Semarang. Skor benar pada pertanyaan yang diajukan ketika post test mengalami peningkatan setelah diberikan penyuluhan (tabel 3).

Tingkat pendidikan penjamah makanan di hotel Patra Jasa Semarang yang sebagian besar SMA memudahkan penjamah makanan menerima informasi yang disampaikan melalui penyuluhan yang diberikan. Selain itu minat dan keseriusan penjamah makanan dalam memperhatikan informasi yang diberikan juga cukup baik walaupun beberapa penjamah makanan terlihat menyepelekan dengan materi penyuluhan yang diberikan.

\section{PEMBAHASAN}

\section{Karakteristik Penjamah Makanan}

Pada penelitian ini, dominasi jenis kelamin penjamah makanan terlihat pada tenaga kerja pria. Sebanyak 13 orang penjamah makanan adalah pria dan 5 orang wanita dengan rasio pria : wanita 2,6:1 (tabel 1). Penelitian serupa di Malaysia menyatakan bahwa sebagian besar $(75,4 \%)$ penjamah makanan adalah pria. ${ }^{11}$

Pendidikan formal yang diterima penjamah makanan tidak menjadi syarat utama untuk memiliki pengetahuan yang cukup untuk menjadi penjamah makanan. Hal ini terlihat walaupun mayoritas (78\%) berpendidikan terakhir SMA, namun pengalaman melalui lama bekerja memiliki peran penting, bahkan sebanyak $83 \%$ penjamah makanan telah bekerja lebih dari 10 tahun. Sejalan dengan data penelitian ini, penelitian di Malaysia menegaskan bahwa penjamah makanan yang telah bekerja selama 6-10 tahun atau lebih memiliki pengetahuan yang lebih baik 
dibandingkan lama kerja kurang dari 1 tahun atau 1-5 tahun. ${ }^{11}$

\section{Perbedaan Skor Pengetahuan Higiene perorangan Penjamah Makanan}

Kepuasan pelanggan hotel sangat bergantung pada kualitas makanan yang higiene dan pengalaman menyantap makanan. Patogen yang berada di area penyelenggaraan makanan dapat berasal dari penjamah makanan, karena itu penting untuk mengetahui apakah penjaga makanan memiliki pengetahuan yang cukup terkait higienitas personal atau tidak. ${ }^{12}$

Sebanyak $72 \%$ penjamah makanan memiliki pengetahuan awal dengan kategori baik (tabel 2). Secara keseluruhan terjadi peningkatan skor benar dari kuesioner setelah pemberian materi penyuluhan. Data di tabel 3 menunjukkan semua penjamah makanan memiliki pengetahuan awal cuci tangan $88,8 \%$, dan meningkat menjadi $100 \%$ setelah diberikan materi penyuluhan. Hal ini sejalan dengan penelitian di Malaysia menyebutkan bahwa sebanyak 98,4\% penjamah makanan memberikan jawaban benar terkait cuci tangan sebelum melakukan pengolahan makanan untuk mengurangi risiko kontaminasi. ${ }^{7}$

Penjamah makanan yang menangani bahan makanan sering menyebabkan kontaminasi mikrobiologis. Mikroorganisme yang hidup pada tubuh manusia dapat menyebabkan penyakit yang ditularkan melalui makanan, yang terdapat pada kulit, hidung, mulut, saluran pencernaan, rambut, kuku, dan tangan. ${ }^{4}$ Oleh karena itu pentingnya higiene perorangan bagi penjamah makanan, salah satunya yaitu untuk mencegah terjadinya kontaminasi dari penjamah makanan ke makanan yang diolah.

Berdasarkan hasil penilaian kuesioner pengetahuan dari 18 orang, diperoleh 13 orang penjamah makanan dengan peningkatan skor pengetahuan dan 5 orang memiliki skor pengetahuan yang sama antara sebelum dan sesudah penyuluhan. Penjamah makanan dengan peningkatan skor pengetahuan sebagian besar memiliki pendidikan terakhir SMA / SMK dan memiliki masa kerja yang cukup lama ( $>10$ tahun). Tingkat pendidikan responden yang sebagian besar SMA dan lama kerja responden yang sebagian besar lebih dari 10 tahun, memberikan efek yang cukup besar terhadap tingkat pengetahuan penjamah makanan.

Hal ini menunjukkan bahwa manajemen penyelenggaraan makanan terutama tentang higiene perorangan di hotel ini dari tahun ke tahun telah mengikuti perkembangan keilmuan. Penjamah makan yang memiliki masa kerja lama semakin tahu bahwa higiene perorangan sangat penting untuk dipatuhi. Pendidikan dengan cara memberikan informasi tentang cara pemeliharaan kesehatan (dalam hal ini higiene perorangan penjamah makanan) akan meningkatkan pengetahuan (penjamah makanan). ${ }^{13}$

Hasil ini sesuai Budiman bahwa tingkat pengetahuan dipengaruhi oleh tingkat pendidikan, informasi, dan lama kerja. ${ }^{13}$ Notoatmodjo mengatakan bahwa pengetahuan biasa diperoleh melalui cara tradisional seperti cara coba-salah, secara kebetulan, cara kekuasaan atau otoriter, pengalaman pribadi, cara akal sehat, sedangkan cara modern melalui metodologi penelitian. ${ }^{10}$ Menurut Budiman 2013, lama kerja merupakan sumber pengetahuan untuk memperoleh kebenaran dengan cara mengulang pengetahuan yang diperoleh dalam memecahkan masalah yang dihadapi. ${ }^{13}$

\section{SIMPULAN}

Sebagian besar penjamah makanan memiliki pengetahuan awal yang baik terkait higiene perorangan. Adanya penyuluhan higiene perorangan mampu meningkatkan pengetahuan seluruh penjamah makanan.

\section{DAFTAR PUSTAKA}

1. Auliya A, Aprilia DN. Pengaruh Hygiene Pengolahan Makanan Terhadap Kualitas Makanan di Hotel Aston Rasuna Jakarta. J Hosp dan Pariwisata. 2016;2(2):216-27.

2. Githiri M, Kimiywe J, Okemo P. Knowledge in food hygiene and hygienic practices differ-in food handlers at a hospital in Nairobi, Kenya. African J Food Sci Technol. 2013;4(1):19-24.

3. Sharif L, Obaidat MM, Al-Dalalah M-R. Food Hygiene Knowledge, Attitudes and Practices of the Food Handlers in the Military Hospitals. Food Nutr Sci. 2013;4(3):245-51.

4. Nasrolahei M, Mirshafiee S, Kholdi S, Salehian M, Nasrolahei M. Bacterial assessment of food handlers in Sari City, Mazandaran Province, north of Iran. J Infect Public Health. 2017;10(2):171-6.

5. Annor GA, Baiden EA. Evaluation of Food Hygiene Knowledge Attitudes and Practices of Food Handlers in Food Businesses in Accra, Ghana. Food Nutr Sci. 2011;2(8):830-6.

6. Idris Ali A, Immanuel G. Assessment of Hygienic Practices and Microbiological Quality of Food in an Institutional Food Service Establishment. J Food Process Technol. 2017;8(8):1-9.

7. Abdul-Mutalib NA, Abdul-Rashid MF, Mustafa S, Amin-Nordin S, Hamat RA, Osman M. Knowledge, attitude and practices regarding food hygiene and sanitation of food handlers in Kuala Pilah, Malaysia. Food Control. 2012;27(2):289 93. 
8. Indonesia KKR. Peraturan Menteri Kesehatan Republik Indonesia Nomor 1096/MENKES/PER/VI/2011 tentang Higiene Sanitasi Jasaboga. Indonesia; 2011.

9. Susanna D, Eryando T, Kusuma A. The Relationship Between Knowledge and Behaviour of Food Handlers to Escherichia coli Contamination in Serving Foods in a Campus. 2015;33(7):1125-31.

10. Notoatmojo S. Ilmu Perilaku Kesehatan. Jakarta: Rineka Cipta; 2010.
11. Nee SO, Sani NA. Assessment of Knowledge, Attitudes and Practices (KAP) Among food handlers at residential colleges and canteen regarding food safety. Sains Malaysiana. 2011;40(4):403-10.

12. Darko S, Mills-Robertson FC, Wireko-Manu FD. Evaluation of some hotel kitchen staff on their knowledge on food safety and kitchen hygiene in the Kumasi Metropolis. Int Food Res J. 2015;22(6):2664-9.

13. Budiman RA. Kapita Selekta Kuesioner: Pengetahuan dan Sikap dalam Penelitian Kesehatan. Jakarta: Salemba Medika; 2014. 